\title{
Mamanda Story: Identity and Creative Industry
}

\author{
Dwi Wahyu Candra Dewi ${ }^{1}$, Agus Nuryatin ${ }^{2}$, Teguh Supriyanto ${ }^{3}$, Ida Zulaeha ${ }^{4}$ \\ \{dewicd0805@gmail.com\} \\ Universitas Lambung Mangkurat ${ }^{1}$ \\ Universitas Negeri Semarang, Indonesia ${ }^{2,3,4}$
}

\begin{abstract}
Mamanda's story began to be unknown to any generation because of the trends of the times. It is necessary to restore the value contained in the Mamanda story, as well as the effort to maintain it. The values contained in the Mamanda story are one of the identities of the Banjar community. This retention of Banjar identity can be done with the creative industry. The study was conducted using qualitative, literature study methods, interactive methods, and heuristic methods. Based on the results of the study, Mamanda's story is often not considered as a characteristic of the Banjar community. While from the story Mamanda can recognize the distinctive characteristics of the Banjar community as his identity. Besides that, it was also found out how the defense of the Mamanda story could be called the creative industry. This creative industry is what he creates t-shirts with quotes from Mamanda's story. The conclusion of this study is the Mamanda story which is one of the identities of the Banjar community. Mamanda quotes can be purchased using creative industries with a dialogue that reads the quotes of dialogue.
\end{abstract}

Keywords: Mamanda story, identity, creative industry

\section{Introduction}

Mamanda's story is an oral literary work in Banjarmasin. Mamanda's story was delivered at the Mamanda show. During this time the attention of connoisseurs of work is on the side of the show. From the side of the story less attention. Millennials in Banjarmasin know little about Mamanda's story. Like in other regions, the millennial generation prefers modern story. At first the Mamanda story was not recorded, either in audio, audio-visual, or manuscripts. Mamanda's story was delivered verbally and it was a concept that was held by the leader of the Mamanda group. Mamanda's story is only a concept then developed by Mamanda players.

Mamanda's story contains story of life in the kingdom, this shows that in ancient times Banjarmasin was indeed an area in the form of a kingdom. However, Mamanda's story are still relevant to today's life. Mamanda's story tells the life of the king, son or daughter, to the people of a kingdom.

The characters in Mamanda's story have an equally important role. The role delivered with the story provides tangible benefits to the audience. With the story displayed, the function of the Mamanda story is clear for the lives of the people of Banjarmasin and its surroundings. The structure, function and meaning contained in Mamanda's story need to be conveyed back to the community. Mamanda's story is a literary work that is inseparable from the influence of development and society. This is as stated by Wellek and Warren (1993) Literature is a social institution, using as its medium language, a social creation [1]. They are conven-tions and norm which could have arisen only in society. But, furthermore, literature 
'represent' 'life'; and 'life' is, in large measure, a social reality, eventhough the natural world and the inner or subjective world of the individual have also been objects of literary 'imitation'.

The first Mamanda story can be enjoyed through the Mamanda theater show complete with its standard. However, based on the development of the Mamanda theater performance, it rarely began. Therefore, the Mamanda story is not very well watched by the audience. The Mamanda show which began to be rare is one of the reasons unknown and developed by the Mamanda story. Research on Mamanda was carried out by Kleden (2001), who examined Mamanda from an anthropological perspective (history, social life, and its development area) [2]. The research needs to be reviewed because it covers the development of Mamanda in accordance with the time of its development. The next study by Wulandari with the title Banjar Cultural Value in the Mamanda Manuscript (2016), the study was only based on the text without an interview with the resource person [3]. Research related to regional literary story was also conducted in the research of Innovation of Suminten Edan Story By Ketoprak Wahyu Manggolo Pati (2018) by Purnomo, Marhaeni and Irianto [4]. The research is creative research, but if applied to Mamanda's story, it is not appropriate because of the innovations made in the story and performances. If from the side of the story to experience innovation, it will result in Mamanda's story not in accordance with the standard and missing its trademark.

The defense of the Mamanda story needs to be done using the creative industry. This is so that the Mamanda story can be enjoyed by all people even though it does not have to be displayed using the Mamanda theater show. This is supported by Michael's opinion in the study entitled Law Enforcement Through 'Ludruk' and Cultural Advent (2018) [5]. Ludruk as a media for law enforcement and cultural progress, even so with Mamanda including the story that were conveyed.

The story of mamanda as one of the works of literature must be maintained because it contains the values of life. This is as stated by Nuryatin (2016) in the HISKI conference that literature is a cultural child that contains the values of life and its existence cannot be separated from the intrinsic elements of the mandate of literature [6].

\section{Methods}

This research is a qualitative research that is emphasized more on Mamanda story research both in terms of structure, function and meaning, as well as maintenance using the creative industries. The data of this study are Mamanda story that have been documented. Research data sources are from interviews with story writers, story of readers from children, adolescents and adults, as well as books about Mamanda. Data analysis techniques, the data were analyzed based on the structure, function and meaning of the Mamanda story, then quotes taken from the Mamanda story to enter the creative industry. Creative industries chosen to keep Mamanda's story from being lost or forgotten. The data analysis technique uses the literature study method, besides that it also uses an interactive method with interviews with nara sources, and also the heuristic method.

\section{Results and Discussion}


Based on the research that has been done, the researchers succeeded in revealing that the Mamanda story is the identity of the Banjar community. This identity can be searched by analyzing the structure, function and meaning of the Mamanda story. Furthermore, the defense of Mamanda's story using the creative industry in the form of a t-shirt with front design is a quote from Mamanda's story.

Table.1 Identity of the Mamanda Story

\begin{tabular}{ccc}
\hline Structure & Function & Meanings \\
\hline Introduction & Literacy & Children's \\
Fill & & Teenagers \\
Cover & & Adult \\
\hline
\end{tabular}

The structure of the Mamanda story is the opening (the introduction of characters, settings, settings, story), contents (problems, peak problems, and problem solving), concluding (messages).

\section{Introduction:}

Mamanda Geger Ganda Manik Sukalima

by Arsyad Indradi

\section{Baladon}

Three people combine singing dance and narration

"Tebu salah saray sarapun, Mun ada nang tasalah kami maminta ampun"

(Music)

(Harapan Pertama and Harapan Kedua enter the trial hall and introduce themselves)

Harapan Pertama : Adinda Harapan Kadua ayu kita masuki balai persidangan, kita siapakan apa-apa yang perlu kita persiapkan hagan acara persidangan.

\section{Fill}

Hamba umpat batakunlah, Paduka.

Raja : Takunakan aja Hadam ai

Hadam : Tapi jangan sariklah

Raja : Ai, kanapa sarik, takunakan ja

Hadam : Paduka manghargailah lawan sanibudaya Banjar

Raja : Ha ha ha itukah Hadam, Beta sangat menghargai senibudaya Banjar. Nanti kita adakan dalam karasmin perkawinan putri Beta, semua kesenian nang ada di kerajaan kita tampilkan dan terus kita bina, kita gali, kita lestarikan, kita bantu sagala apa nang diperlukan seniman dan grup keseniannya, tiap tahun kita adakan lomba baik kesenian yang sudah ada lawan berkreasi, kita beri hadiah seni lawan seniman yang berprestasi. Sabuting lagi Hadam ai, kita dirikan sekolah guru kesenian.

\section{Cover:}

Hadam : Paduka Putra jangan kada ingatlah apa nang hamba padahakan samalamlah, kalamahan Panglima Perang Kerajaan Dundung Wowo Sagara.

Putra Raja : Inggih ulun Paman Hadam. Ulun kada lupa. Terima kasih banar wan sampaian. 
(The king and other staff leave the lounge) Looks at the readiness of the Royal forces Ganda Manik Sukalima and Royal forces Gumilang Kaca Salaksa headed by the War Commander Gantar Gandari Buana Paksi and Raden Guntur Guntala.

(The dance performance and completion of this dance, the story is finished. Closed with a thank you song)

The function of the Mamanda story as literacy, language and literature learning material and materials for making Mamanda scripts. This is a continuation of previous research in relation to Mamanda as a means of correcting Indonesian language in Banjar in 2011 by Dwi Wahyu C.D. [7]. Based on the results of interviews with resource persons, Sirajul Huda, one of the maestros of Mamanda (a script writer and Mamanda player), that Mamanda's story could be used as literary literacy, teaching materials and competition materials. Likewise with the opinion of Arsyad Indardi as a Mamanda scriptwriter. This is related to the opinion of Rondiyah, Eko, and Sadhono (2017) that literature, language and culture in the Mea era are related [8]. As well as in learning, literature fosters character education. This was confirmed by Neina, Mardikantoro, and Supriyanto (2015) that character education is directed at giving pressure to certain values and helping students to understand, pay attention to, and perform these values in daily life [9].

Mamanda's story has a deep meaning for the life of the Banjar people in particular and the community outside of Banjar in general. The meaning of the Mamanda story includes meaning for children, adolescents and adults. For children, Mamanda's story has the meaning of arousing imagination and enhancing insights into literary culture and history. The meaning of the Mamanda story for adolescents is to foster a sense of belonging to local wisdom to help preserve and maintain. In accordance with Wardani, Rustono, Nuryatin (2017) opinion that modernization erodes local culture to be westernized [10]. So, with the presence of local people like the Mamanda story, the millennial generation will not escape the local wisdom they have. The meaning of the Mamanda story for adults is to provide a reflection of community life and social criticism of things that are not in accordance with the rules. From the structure, function, and meaning of the Mamanda story can be used as the Mamanda story identity as one of the characteristics of Banjar literature. Based on the discussion, it can be mentioned the meanings of the Mamanda story as a whole, namely the meaning of identity, the meaning of education, the meaning of innovation, and the meaning of cultural preservation. This refers to Sari's opinion (2011: 160) regarding the meaning of revitalizing tradition [11]. These meanings are the result of the defense of Mamanda's story

The defense of Mamanda's story uses the creative industry. Anoegrajekti (2013) explained that local literature and using culture can be realized through the creative industry [12]. Likewise, the Mamanda story needs to be preserved and maintained through the creative industry. The creative industry chosen is the loading of quotations from the Mamanda story, whether in the form of dialogues of characters or storytellers (balladons) printed on t-shirts or cloth bags. Apart from being a means of maintaining Mamanda's story, these shirts and bags can also be used as souvenirs. The selection of this creative industry is based on the idea that there are no souvenirs that carry the value of regional literature to be appointed or introduced to domestic and foreign tourists. This is also supported by the opinion of Suarka and Cika (2014), that folklore can be a source of creative economy [13].

Creative things can be sourced from local literature to produce industries, creative economics. This is basically in accordance with the opinion of Nursa'ah, Idiatmoko and Nugroho (2016) which states that oral literature is the creativity of humans who live in groups of people who own it and are inherited from generation to generation orally from generation to 
generation [14]. Thus, there is nothing wrong if Mamanda's story is used as an object to be preserved and maintained through the creative industry. Nurjanah (2013) also explained that the development of creative industry business programs could be carried out by higher education [15]. Higher education as a developer because of this higher education will be born professions that compete according to the times. The development of the era made the need for the development of creativity as a form of fighting power of defense.

The novelty that emerged from this research was the existence of a creative process to elevate regional literature (the Mamanda story) as an identity to be known not only by the Banjar community but also outside of Banjar. Thus, this study provides benefits for the preservation and retention of the Mamanda story.

\section{Conclusion}

Mamanda's story is the identity of the Banjar community seen from the structure, function and meaning of the Mamanda story. The defense of Mamanda's story can use the creative industry by printing excerpts of story or characters' dialogues on t-shirts or bags as souvenirs. Thus, local literature (Mamanda story) can be maintained, and can also be modified and innovated to keep growing and developing. 


\section{References}

[1] Wellek and Warren. 1993. Literary Theory. Jakarta: Gramedia.

[2] Kleden, Ninuk. 2001. Mamanda Theaterand Defining the Banjar Identity Back. on line. http://journal.ui.ac.id/index.php/jai/article/view/3441 accessed December 12, 2015.

[3] Wulandari, Noor Indah. 2016. Banjar Cultural Value on Mamanda Manuscripts. Journal of Language, Literature and Learning. Vol. 2 No. 1.

[4] Purnomo, Marhaeni, and Irianto. 2018. Innovation of Suminten Edan Story By Ketoprak Wahyu Manggolo Pati. Journal of Art Research and Education Harmonia Vol. 18 No.2

[5] Michael, Tomy. 2018. Law Enforcement Through 'Ludruk' and Cultural Advancement. Asia Pacific Froud Journal Vol. 3 No. 1.

[6] Nuryatin, Agus. 2016. Sastra Dalam Pendidikan, Pendidikan Dalam Sastra. Proceeding Literature and Nation Character Building. The 23rd HISKI Conference on Literature.

[7] Dewi. 2011. Mamanda Indonesian Language Correctional Facilities in Banjar. PIBSI Conference Paper. Semarang.

[8] Rondiyah, Eko, and Sadhono. 2017.Literary Learning Through Cultural Languages to Improve National Character Education in the MEA Era. Education and Language International Conference Proceedings Center for International Language Development of University. May 2017 (p.141-147).

[9] Neina, Mardikantoro, and Supriyanto. 2015. Development of Enrichment Books Writing Character Values of Children's Story Based on Content and Language Integrated Learning (CLIL). Seloka Journal 4 (2). http://journal.unnes.ac.id/sju/index.php/seloka. Accessed June 23, 2019.

[10] Wardani, Rustono, and Nuryatin. 2017. Analysis of Anecdotal Texts Containing Local Character and Wisdom as Enrichment of Indonesian Language Teaching Materials in High School. Indonesian Literature Language Education Journal. JPBSI $6 \quad$ (2) http://journal.unnes.ac.id/sju/index.php/jpbsi.

[11] Sari, Darwan. 2011. Revitalizing the Oral Tradition of the Southeast Sulawesi Muna Community in the Globalization Era. Thesis. Univ. Udayana: Denpasar

[12] Anoegrajekti.2013. Local Literature and Creative Industries: Revitalizing Using Literature and Culture. Journal of Atavism, Vol. 16 No. December 2, 2013 (183-197).

[13] Suarka and Cika. 2014. Utilization of Folklore as a Source of Creative Economy in Bali's Tourist Destinations. ATAVISME, Vol. 17, No. 1, pp. 17-83

[14] Nursa'ah, Indiatmoko, and Nugroho. 2016. Folklore in Banjarnegara Regency. Sutasoma Journal. http://journal.unnes.ac.id/sju/index.php/sutasoma.

[15] Nurjanah, Siti. 2013.Analysis of the Development of Creative Industrial Business Programs Implementation through Higher Education. JMA. Vol.18 No.2 October-November 2013. 